\title{
The Effects of Utilising the Concept Maps in Teaching History
}

\author{
Subadrah Madhawa Nair
}

Assoc. Prof., Faculty of Education and Languages, HELP University, Malaysia, m.subadrah@help.edu.my

\author{
Moganasundari Narayanasamy \\ Permatang Rawa Secondary School, Bukit Mertajam, Penang, Malaysia, \\ mogsel@gmail.com
}

\begin{abstract}
Teaching History is a tough and challenging task for teachers because most students consider History as a boring subject. Many studies indicate that students are not interested in learning History. This paper is based on a quasi-experimental study conducted to investigate the effects of utilizing the concept map method in the teaching of History in secondary schools. The researchers investigated whether the use of concept maps in the teaching of History helped the subjects from the experimental group to answer history questions better than the control group. The researchers also investigated whether this method helped to enhance students' interest in the learning of History. The findings of this research indicated that the utilisation of the concept map method significantly improved students' achievement and interest in History. Findings of this study support the theory of meaningful learning and utilization of concept maps. Moreover, the findings have strong pedagogical implications on teaching of History. As such, the practical implications are that the Ministry of Education should train History teacher how to utilize concept maps in teaching of History.
\end{abstract}

Keywords: teaching history, concept maps, theory of meaningful learning, Malaysian secondary schools

\section{INTRODUCTION}

The History subject taught in schools is very important in nurturing the spirit of citizenship and aiding in the foundation of nation building. Challenges in teaching history in schools have been a great concern among teachers, educationist and historians. Steeves (1998) argued that the school curriculum specialists have often included such social issues as race relations, teenage violence, patriotism, civil rights, and the family, in history or civics classes. Crabtree (2001) highlighted that many of the elementary school children in the United States do not like to study history. Some complained about history as a "boring subject," and others felt there was no use in studying about people and events of the past. In Malaysia History has become a booster

Citation: Nair, S. M. \& Narayanasamy, M. (2017). The Effects of Utilising the Concept Maps in Teaching History. International Journal of Instruction, 10(3), 109-126. https://doi.org/10.12973/iji.2017.1038a 
for economic development and social change in addition, to instilling the spirit of patriotism and pride for the nation (Malaysian Secondary School Integrated Curriculum Syllabus Description, History; 2002). Therefore, in the Malaysian Schools History Curriculum, has been made a compulsory subject at the secondary school level (Malaysian Ministry of Education, 1989). Unfortunately, most students think History is boring and not an important subject. Leibowitz (2006) stressed that the type of approach used by teachers is crucial in increasing students' motivation, promoting understanding of the subject matter and furthering students' skills development in the study of History.

\section{Problem Statement}

Teaching History is a tough and challenging task for teachers because most students consider History as a boring subject telling of the past events. Students find it difficult to visualize and organize information. In addition, students require intellectual maturity and cultural literacy in order to understand History. History teachers should also employ the right strategies to create a conducive learning environment to enhance students' understanding and interest in History. The majority of the History teachers' still practiced teacher oriented teaching and use the 'chalk and talk' method in the classroom. According to Konting (2004), History teaching activities in classes are still geared towards an exam oriented manner. As such, the teaching process fails to develop students' understanding and thinking skills. According to Jamil (2003), students tend to lose interest in learning History if teachers fail to apply the right strategies in the process of teaching and learning. Similarly, findings by Muthiah (2010) showed that students were less interested in learning History because $85 \%$ of the History teachers in her study preferred to use teacher centered methods in teaching History and only $15 \%$ of them were in favour of using student centered approaches. Her findings also showed that all $100 \%$ of the History teachers in her study only placed emphasis on choosing selected topics in teaching History and ignored the topics that had already been tested in the previous national examinations. In other words the teaching and learning of History was exam oriented.

In a study carried out by Mohd Din (2005) and Selamat (2004) showed that History teachers were concerned about the importance of achieving the main objectives in teaching History. The process of teaching and learning emphasized rote learning and memorizing dates and facts, based solely on the textbook and purely exam oriented. As such, students are easily bored during History lessons and lose their interest in learning History. Studies by Novak (2002, 2005, 2010), and Novak and Gowin (1984) showed that the use of mapping concepts helped students to learn because students were trained to translate abstract information from the text into graphic representation which promote sensible, logical and meaningful learning. The History subject contains a lot of past information which is abstract, complex and difficult to be understood by students. Therefore, by using the concept map method, students are trained to organize abstract information in History in graphical form which is much easier to understand. As stressed by Novak (2010), concept mapping is a tool used to develop students' meta-cognitive strategies where the learner takes charge of his own learning in a meaningful way. There are very few studies on the usage of concept map in teaching history, most of the studies 
employed concept maps in teaching the science subjects. Thus, this research focuses on the effects of utilizing concept map method (Novak \& Gowin, 1984) in the process of teaching and learning History.

\section{Research Objectives}

The first objective of the research is to identify the effects of utilizing concept map method on students' achievement in History. The second objective is to ascertain whether the utilization of the concept map method enhances students' interest in learning History. The effects of utilizing Novak's concept map method on students' achievement in History are tested in the form of multiple choice type questions, structured questions and overall History questions (multiple choice \& structured questions). The effects of using the concept maps on students' interest in learning History are measured by using a set of questionnaires designed for this purpose.

\section{Research Hypotheses}

Four null hypotheses were constructed and tested in this research on a significant level of 0.05 . The hypotheses are as follows:

Ho 1: There is no significant difference in scores between the experimental group and the control group in the multiple choice type questions in History.

Ho 2: There is no significant difference in scores between the experimental group and the control group in the structured questions in History.

Ho 3: There is no significant difference in scores between the experimental group and the control group in their overall achievement in History (multiple choice type and structured questions).

Ho 4: There is no significant difference in scores between the experimental group and the control group in their interest in learning History.

\section{LITERATURE REVIEW}

The concept map was introduced by Novak and Gowin (1984), and this method is based on Ausubel's (1963) meaningful learning theory which states 'Meaningful learning involves the assimilation of new concepts and propositions into existing cognitive structures'. According to Novak and Gowin (1984:15) the concept map is a '... schematic device for representing a set of concept meanings embedded in a framework of proposition.' The concept map method is also based on the constructivist approach to learning that emphasizes new knowledge building based on students' existing knowledge. This method emphasizes the relationship between concepts clearly. Besides that, concepts are also hierarchically arranged from top down and concepts are stated in boxes or circles and labelled. Furthermore, under the concept map method, concepts are linked using straight lines or arrows and the link word is written on the lines or arrows. The linking words serve to create propositional statements that ultimately give the meaning that the learner is attempting to convey (Daley, 2010). The first concept is more inclusive and has a broader scope followed by other concepts below which are less inclusive (Novak \& Canas, 2004). In the process of learning History, concept maps help students to understand History concepts in a meaningful way because students are 
engaged in arranging concepts from the general to the specific and students can also see the relationship between concepts comprehensively in a graphical form. In other words, by creating concept maps students are able to use the constructivist learning strategy because they are able to analyse and give meaning to what they are learning.

\section{The Effects of Concept Maps}

Study by Novak and Gowin (1984) showed that the concept map method enables teachers to describe concepts that occur in certain texts and engage students actively in the learning process. Studies by Novak $(2002,2005,2010)$ also showed that the use of concept maps in learning Science helped students to understand and organize Science concepts in a more meaningful manner and enhanced their understanding. Their findings also showed that students can organize complex concepts graphically by using the concept maps. In addition, Novak and Canas (2006) asserted that the use of concept maps can improve students' memory because through it, students can save the knowledge in an organized manner in their cognitive structures in the long term memory. However, Kinchin (2014) stressed that teachers should be clear about the benefits of mapping activity and should convey the information to the students for effective learning. A study conducted by Sen@ Thomas (2002) showed the utilization of the concept maps method in the learning of Science helped the Form One students (13 years old) to understand Science concepts clearly and enhanced their knowledge in Science.

Kwang (2000) also emphasized that students' performance in the Biology subject improved significantly after being taught using the concept maps. Similarly, a study conducted by Karakuyu (2010) also showed that instructions given by the teacher and drawing concept maps significantly improved the achievement of the experimental group in Physics compared to the control group who were subjected to the conventional method. Asan ((2007) carried out a research to determine the effects of incorporating concept maps on the achievement of Fifth Grade students learning Science. The findings of the study indicated that the experimental group who were taught using the concept map method performed significantly better than the control group who were exposed to the conventional method. Studies by Kaur (2007), Aziz and Jair (2009), and Jayaraman (2009) also revealed that the use of concept maps facilitated the learning process and was able to enhance students' achievement significantly. Findings by Chiou (2008) also indicated that concept mapping is an effective strategy in enhancing students' achievement in the Accounting subject.

Al-Shaer (2014) utilized concept mapping as a prewriting strategy to help Palestinian EFL learners generate argumentative composition. The findings of this study revealed that concept mapping can produce more autonomous EFL learner. The students were also successful in generating new ideas and relationship, and their writing reflected better ability to think for themselves. Study by Zwaal and Otting (2012) concluded that concept mapping enhanced problem-based learning among students, especially in the decision-making process and the communication. However, in contrast to previous research their research showed that concept mapping failed to bring about creativity and better understanding of certain problem. On the other hand, study by George-Walker 
and Tyler (2014) showed that collaborative concept mapping process provided the team with meaning making mechanism through which to share understanding and explored the teams' potential capacities as stressed by Ausubel (1963). In other words the team was able to work in a collaborative manner for team dialogue and co-construction that was focused, hands-on and visual. Miandoab, Mostafaef and Ghaderi (2012) examined the effects of concept mapping on students learning performance in a history course. The result showed that subjects from the experimental group performed significantly better than the control group. Similarly, a study by Thirumalar (2006) also revealed that employing a concept map strategy enhanced students' understanding and their achievement in History. Therefore, literature review of past studies conducted on the effect of concept maps indicated the positive effects of the method on students' understanding, achievement, problem solving, team collaboration, motivation, attitude, and interest in learning. However, most of the studies are conducted on science subjects and studies on the effect of concept map in teaching History is very limited. As such, this study investigates the effects of using concept map in teaching History.

\section{Effects of Concept Maps on Students' Interest in Learning}

Novak and Gowin (1984) stressed that the utilization of concept maps promotes positive self-concepts and positive attitudes towards learning. Several studies have also indicated that the utilization of concept maps enhances students' interest in learning. A research conducted by Isnawati (2000) showed that the use of concept maps increased university students' interest in learning Carbon Chemistry. A study by Tirumalar (2006) revealed that students have positive attitudes towards learning History after being taught using the concept map method. Similarly, findings by Kaur (2007) indicated that students' interest in learning literature components in the Malay Language was enhanced significantly when the teacher used the concept map method. Findings by Nair (2009) also showed that Form Four (16 years old) students' interest in learning Elementary Economics increased after using concept maps. A study conducted by Karakuyu (2010) also showed that students had more positive attitudes towards learning Physics as a result of using the mapping concept. Findings by Chiou (2008) showed that $84 \%$ of the students in the study felt that they liked using concept mapping to assist them in learning Accounting.

\section{METHOD}

This research employed a quasi-experimental design (pre- and post-test) as suggested by (Creswell, 2014: 336), and was conducted over eight weeks. The research samples were divided into two groups, namely the experimental group and the control group. During the first week, students from the experimental group and the control group were given a pre-test and questionnaire on interest in learning History. Over the next six weeks the experimental group was taught using the concept map method and the control group was taught using the conventional method. In the eighth week both groups were given the post-test and questionnaire on interest in learning History. 


\section{Research Procedure}

Prior to the experiment, the researchers trained the teacher from the experimental group on the teaching steps using the concept map method. The researchers also provided the topics, teaching objectives, complete teaching lessons and teaching aids (concept maps) for six weeks. The researchers also trained the teacher teaching the experimental group on how to draw concept maps according to procedures suggested by Novak and Gowin (1984). On the other hand, the teacher from the control group was only given the topics and the learning objectives for six weeks, as in the experimental group. During the first week, students from both groups were given the pre-test and the questionnaire on interest in learning History. From the second week to the seventh week, the experimental group was taught using the concept map method, and the control group was taught using the conventional method. The researchers observed the teaching process in the experimental group to make sure that the teacher followed all the teaching steps that had been prepared by the researchers. The researchers also observed the teaching of the control group four times to make sure that the teacher was not using the concept map method and only utilized the conventional method.

In the experimental group, after the set induction, the teacher related the set induction to the lesson topic of the day. Following that, the teacher explained the objectives of the lesson to the students and introduced the topic. The teacher then discussed the topic with the students using concept maps. Then the teacher taught the students how to construct concept maps in a meaningful way. Then the students were divided into groups (five to six students in a group) and they were given the task of drawing their own concept maps on a given topic (students used textbooks and handouts as their references). The teacher facilitated the students in constructing concept maps during the group work. Then each group was required to do their group presentation and the teacher helped the students to modify and correct any misconception. The teacher then evaluated the students' understanding of the topic during the group presentation. At the end of the lesson the teacher asked the students to reflect on the concept maps that they had constructed. This procedure was repeated over the six weeks (three times a week).

In the control group, after the set induction the teacher introduced the lesson. Then the teacher discussed the topic using the textbook and other teaching aids, except concept maps. The teacher then evaluated the students' understanding by asking questions. Then the teacher concluded the lesson. This procedure was repeated over six weeks (the topics and the duration of teaching was the same as in the experimental group).

\section{Research Samples}

In this study, the researchers used homogenous samples (Creswell, 2014), consisted of 70 Form Two students (fourteen years old) from two sub-urban secondary schools in the Nibong Tebal district of Penang, Malaysia. The population of Form Two students in both the schools were 310. Each school represented one research group so that the teaching method practiced on one group would not influence the other group. The student number in the experimental group was 36 , while the control group consisted of 34 students. The students in both groups were average achievers in History and other 
academic subjects, seen from their final year (2009) examination results in Form One. The students from both groups are also similar in term of gender and ethnic composition (Malay, Chinese, and Indian).

\section{Research Instruments}

The researchers used two types of research instruments, as follows:

i) Pre-test and post-test for measuring students' achievement in History.

ii) Questionnaires on students' interest in learning History.

The contents of the pre-test and post-test were the same, consisting of 30 multiple choice type questions and 10 structured questions, which required students to write their answers in the blank spaces given. The total marks for the multiple choice type questions were 30 and 20 for the structured questions. The total marks for both sets of questions were 50 .

To obtain the validity of the instruments the researchers asked two teachers who are heads of the History panels, with more than 10 years of experience in teaching History to check and validate the questions and answer schemes for the pre-test and post-test, to ensure they were suitable for Form Two students. The teachers were not from the sample schools; this was to avoid biases. The reliability of the multiple choice type questions was tested using KR21 and KR20 and the findings indicated the questions were reliable $(\mathrm{KR} 21=81, \mathrm{KR} 20=87)$.

The questionnaire on students' interest in History consisted of 10 items and they were graded based on the Likert scales. The researchers had taken 10 items from the questionnaires used by Muthiah (2004), and modified it for the purpose of the present research. The score for each given response was based on a 4-point Likert scales, 4 points were given for the option, 'totally agree', 3 points for 'agree', 2 points for 'disagree' and 1 point for 'totally disagree'. The scores for the 10 items were totalled up to represent students' scores for interest.

Prior to the actual study, a pilot study was carried out on 34 Form Two students in a Secondary school in Nibong Tebal, Malaysia where by the features of the school and students' academic performance were similar to that of the students in the experimental group and the control group. Findings from the pilot study showed that students could understand every instruction and question to be given in the pre-test, post-test and the questionnaires. The reliability of the questionnaire was tested using 'Cronbach's Alpha'. The Alpha value for the questionnaire in this research was 0.784. According to Sekaran and Bougie (2013), if the reliability is more than 0.60 the questionnaire is suitable and can be used in the research. As such, the finding confirms that the questionnaire was reliable and can be used in the research. The data obtained from the pre-test and questionnaire (prior to intervention) was analysed using the independent sample t-test and data from the post-test were analysed using ANCOVA test (analysis of Covariance).

\section{FINDINGS}

The pre-test findings in Table 1 show that there are no significant differences in scores between the experimental group and the control group in the multiple-choice type 
questions (mean difference $=0.64, \mathrm{t}=0.64, \mathrm{df}=68, \mathrm{p}=0.40$ ); structured questions (mean difference $=0.83, \mathrm{t}=-1.50, \mathrm{df}=68, \mathrm{p}=0.14$ ) and overall questions (mean difference $=0.23, t=-0.22, \mathrm{df}=68, \mathrm{p}=0.83$ ). As for interest in learning History, there was a significant difference between the scores of the experimental group and the control group (mean difference $=0.17, \mathrm{t}=2.07, \mathrm{df}=68, \mathrm{p}=0.04$ ). As such the data from the post- test and the post-interest questionnaire were analysed using the ANCOVA test. As stressed by Gay, Mills and Airasian (2006) the ANCOVA test is used to eliminate the score differences between the experimental group and the control group in the pre-test. The scores of the pre-test and pre-interest was used as covariant in analysing the data from the post-test (using the ANCOVA) test, as shown in Table 1:

Table 1

Findings of the independent samples t-test for the pre-test

\begin{tabular}{|c|c|c|c|c|c|c|}
\hline Component & Group & $N$ & $\begin{array}{l}\text { Mean } \\
\text { Difference }\end{array}$ & $t$ value & $d f$ & Sig. \\
\hline Multiple-choice Type Questions & Experimental & 36 & 0.64 & 0.84 & 68 & 0.40 \\
\hline & Control & 34 & & & & \\
\hline Structured Questions & Experimental & 36 & 0.83 & -1.50 & 68 & 0.14 \\
\hline & Control & 34 & & & & \\
\hline Overall Questions & $\begin{array}{l}\text { Experimental } \\
\text { Control }\end{array}$ & $\begin{array}{l}36 \\
34\end{array}$ & 0.23 & -0.22 & 68 & 0.83 \\
\hline Interest & $\begin{array}{l}\text { Experimental } \\
\text { Control }\end{array}$ & $\begin{array}{l}36 \\
34\end{array}$ & 0.17 & 2.07 & 68 & $* * 0.04$ \\
\hline
\end{tabular}

$* \mathrm{p}<0.05$

Ho 1: There is no significant difference in scores between the experimental group and the control group in the multiple choice type questions in History.

Table 2

The ANCOVA Test for scores in multiple choice questions in post-test

\begin{tabular}{llllll}
\hline Source & $\begin{array}{l}\text { Sum of } \\
\text { Squares }\end{array}$ & $d f$ & Mean Square & $F$ & Sig. \\
\hline Corrected model & 2236.118 & 2 & 1118.06 & 205.99 & .000 \\
\hline Interception & 505.04 & 1 & 505.04 & 93.05 & .000 \\
\hline Pre-Multiple Choice Type Questions & 256.37 & 1 & 256.37 & 47.23 & .000 \\
\hline Group & 1818.61 & 1 & 1818.61 & 335.06 & .000 \\
\hline Error & 363.65 & 67 & 5.43 & & \\
\hline Total & 22694.00 & 70 & & & \\
\hline Corrected Total & 2599.77 & 69 & & & \\
\hline
\end{tabular}

$* \mathrm{p}<0.05$

The data analysis of multiple choice type questions in the post-test showed the mean score for the experimental group was higher (mean $=22.11, \mathrm{SD}=3.26$ ) compared with the control group (mean $=11.47, \mathrm{SD}=2.74$ ). The findings from the ANCOVA test in Table 2 indicate that the scores of the experimental group in the multiple choice type questions are significantly higher compared with the control group $(\mathrm{F}=335.06 ; \mathrm{df}=1 ; \mathrm{p}$ 
$=0.000)$. These results show that the use of the concept map method increased the experimental group's scores succesfully in the multiple choice type questions compared with the control group. Utilization of concept maps has positive effects on the achievement of students from the experimental group. The findings do not accept null hypothesis 1 .

Ho 2: There is no significant difference in scores between the experimental group and the control group in the structured questions in History.

Table 3

The ANCOVA scores for structured questions in the post-test

\begin{tabular}{llllll}
\hline Source & Sum of Squares & $d f$ & $\begin{array}{l}\text { Mean } \\
\text { Square }\end{array}$ & $F$ & Sig. \\
\hline Corrected model & 793.977 & 2 & 396.99 & 189.49 & .000 \\
\hline Interception & 211.07 & 1 & 211.07 & 100.75 & .000 \\
\hline Pre- structured Questions & 179.83 & 1 & 179.83 & 85.84 & .000 \\
\hline Group & 717.35 & 1 & 717.35 & 342.41 & .000 \\
\hline Error & 140.37 & 67 & 2.10 & & \\
\hline Total & 9986.00 & 70 & & & \\
\hline Corrected total & 934.34 & & & &
\end{tabular}

$* \mathrm{p}<0.05$

The data analysis for the structured questions in the post-test shows that the mean score for the experimental group is higher ( mean $=14.25, \mathrm{SD}=2.06$ ) than the control group (mean $=8.32, \mathrm{SD}=2.28$ ). The ANCOVA test results shown in Table 3 reveal that the scores of the experimental group are significantly higher than the control group $(\mathrm{F}=$ $342.41 ; \mathrm{df}=1 ; \mathrm{p}=0.000$ ). This findings show that the use of the concept map method successfully increased the experimental group's scores in answering the structured questions compared with the control group. The students from the experimental group benefited from concept map and were able to understand and remember the subject matter better compared to their counterparts in the control group. This finding fails to accept null hypothesis 2 .

Ho 3: There is no significant difference in scores between the experimental group and the control group in their overall achievement in History (multiple choice type and structured questions).

Table 4

The ANCOVA overall achievement in History in post-test

\begin{tabular}{llllll}
\hline Source & Sum of Squares & $d f$ & Mean Square & $F$ & Sig. \\
\hline Corrected Model & 5527.444 & 2 & 2763.72 & 366.12 & .000 \\
\hline Interception & 604.47 & 1 & 604.47 & 77.67 & .000 \\
\hline Pre-overall & 808.35 & 1 & 808.35 & 103.87 & .000 \\
\hline Group & 4821.03 & 1 & 4821.03 & 619.47 & .000 \\
\hline Error & 521.43 & 67 & 7.78 & & \\
\hline Total & 61885.00 & 70 & & & \\
\hline Corrected Total & 6048.87 & 69 & & &
\end{tabular}


The data analysis of the overall questions (multiple choice type and structured questions) in the post-test shows that the mean for the experimental group is higher (mean $=36.22, \mathrm{SD}=4.30)$ compared with the control group (mean $=19.79, \mathrm{SD}=4.54)$. The results of the ANCOVA test shown in Table 3 indicate that the experimental group performed significantly better than the control group $(\mathrm{F}=619.47 ; \mathrm{df}=1 ; \mathrm{p}=0.000)$. These results show that the use of the concept map method successfully increased the scores of the experimental group in their overall achievement for History. These findings fail to accept null hypothesis 3 .

Ho 4: There is no significant difference between the experimental group and the control group in their interest in learning History.

Table 5

The ANCOVA test for interest in learning History after the intervention

\begin{tabular}{llllll}
\hline Source & Sum of Squares & $d f$ & Mean Square & $F$ & Sig \\
\hline Corrected model & 64.284 & 2 & 32.14 & 586.10 & .000 \\
\hline Interception & 5.63 & 1 & 5.63 & 107.72 & .000 \\
\hline Pre Interest & 3.27 & 1 & 3.27 & 59.64 & .000 \\
\hline Group & 50.91 & 1 & 50.91 & 928.29 & .000 \\
\hline Error & 3.67 & 67 & .06 & & \\
\hline Total & 573.41 & 70 & & & \\
\hline Total Corrected & 67.96 & 69 & & & \\
\hline
\end{tabular}

$* \mathrm{p}<0.05$

Data analysis of student interest in learning History after the intervention showed that the mean for the Experimental Group was higher $(\min =3.59, \mathrm{SD}=0.33)$ compared to the control group $(\min =1.72, \mathrm{SD}=0.31)$. The ANCOVA test results highlighted in Table 4 clearly show that the scores of experimental group are significantly higher for interest in history compared with that of the control group $(\mathrm{F}=928.29 ; \mathrm{df}=1 ; \mathrm{p}=0.000)$. This result does not accept the null hypothesis 4 . This result also shows that the concept map method successfully raised the experimental group's interest in learning History compared with the control group.

\section{DISCUSSION}

The findings of this study showed that the concept map method increased students' scores in multiple choice type questions and enhanced their memory (Kaur, 2007; Nair, 2009; Thirumalar, 2006). These findings also support the findings by Asan (2007) which indicated that concept mapping is an effective tool in enhancing students' achievement when answering multiple choice type questions.

The concept map method has a significant effect on students' achievement in answering multiple choice type questions because it enhances students' understanding of concepts in History as well as enhancing their memory. As stressed by BouJaoude and Attieh (2008) the concept map is a study tool which helps to enhance students' achievements. In rote learning students fail to make connections between previous knowledge and new knowledge, and also fail to make connections between concepts. The construction of concept maps has benefited students from the experimental group in understanding the 
key concepts and its relationship with other concepts in History and students are also able to relate their background knowledge to new information. Besides that the students from experimental group were also engaged in a group presentation. Before the group presentation every group was engaged in active discussion in preparing concept maps to do meaningful presentations. This enabled the students from the experimental group to master the subject matter in depth and perform significantly better than the control group in answering the multiple choice type questions (Novak, 2005, 2010).

The experimental group also performed better in answering structured questions because the concept maps helped the students to understand important concepts in History and enhanced their problem solving skills. The positive effects of utilizing concept maps have been the outcomes of numerous studies (Karakuyu, 2010; Kwang, 2000; Sen@ Thomas, 2002) showed that the concept map method can help students to build clear concepts in their cognitive structures and succeed in raising students' achievement. As stressed by Novak (2010), while constructing concept maps, students from the experimental group were engaged actively in organizing the information in a meaningful way. As such their experiences in filling in information on concept maps help them to have a better understanding of History. In the process of constructing concept maps, the students work collaboratively in groups, interact with group members and explore the meaning of what they have learned (Ausubel, 1963). They also learn to think, organise the information, develop knowledge and visualise the concepts using links and crosslinks (Novak \& Canas, 2006) and these help them to perform better than their counterparts in the control group. Therefore, the experimental group was able to fill in information more accurately while answering structured questions during post-test compared to the control group.

The findings of this study show that students from the experimental group were able to understand the chapter on Nationalism in Malaya clearly by constructing concept maps in groups. The utilization of concept map enhanced the overall achievement of students from the experimental group because they were able to relate all the information in a meaningful way. These findings are parallel to the findings by Thirumalar (2006), Asan (2007), Aziz and Jair (2009), Karakuyu (2010), and Zwaal and Otting (2012), which indicated that the utilization of the concept map method enhances students' achievement significantly.

The results of the present study support research findings by Novak $(2002,2005,2010)$ and Pudelko, et al. (2012), which showed that the use of concept maps helped students to construct clear concepts and knowledge learnt can be kept in the cognitive structures over a long term and students are able to retrieve and use the knowledge when needed. Conversely, students from the control group faced difficulty in constructing clear concepts for History because they were more engaged in rote learning and were thus unable to retrieve information from memory quickly and accurately compared with the experimental group. Besides that students from the experimental group develop metacognitive strategies where by they take charge of their learning in a meaningful way and this helps them to understand the subject matter better than the control group. 
The positive effect of the utilising concept map has been the outcome of many studies where students' interest in learning, increased significantly (Chiou, 2008; Kaur, 2007; Isnawati, 2000; Thirumalar, 2006). The use of the concept map method in this study involved students actively in the History lesson, thus it raises students' interest in History. Karakuyu (2010) also emphasized that students had more positive attitudes towards learning when they were engaged in drawing concept map. By constructing concept maps in learning History, students from the experimental group were able to simplify and present the information on Nationalism in Malaya via graphical representation. Besides, students also had a better understanding and were able to make connections between concepts. In addition, students had a better understanding in History. Thus, their interest in learning History was enhanced compared with the control group.

In this study, students from the experimental group also engaged actively in group presentation for six weeks. They enjoy working collaboratively and always interact with their friends to do a meaningful group presentation. The elements of fun and enjoyment in learning History could also have contributed in enhancing their interest in History. As for the students from the control group they were more engaged in rote learning and the lessons were more teacher centred. They listen to the lecture-style explanation from their teacher and copy the notes given by the teacher. Passive learning environment in the control group failed to enhance their interest in History as experienced by their counterparts in the experimental group.

\section{CONCLUSION}

This research has revealed several important findings. The utilization of the concept map method in teaching History was able to raise students' achievement significantly for multiple choice type questions, structured questions and overall questions. Apart from that, the concept map method was able to raise students' interest in learning History significantly. This method engaged students actively in the learning process because students are actively involved in organizing information and history concepts in a simplified graphical form and they were able to give meaning to the graphic content. In other words, students were engaged in constructivist learning strategies where by the learning process is more student centred and students are able to relate their prior knowledge to new information. This enabled students to understand abstract concepts in History clearly and save the information in their cognitive structures over the long term and use it again when necessary.

The use of the concept map method also had a positive effect on students' interest towards learning History because by constructing concept maps, students can understand the interrelationships between concepts in History. The experimental group understood what they learned and this raised their interest in learning History. Students from the experimental group also engaged in a fun learning while organizing the history information in the process of drawing concept maps. They also enjoyed doing the group presentations and received a lot of inputs from friends and their class teacher. The concept of fun learning and active engagement in the process of learning has enhanced the students' interest towards learning History. 
These findings support the theory of meaningful learning and utilization of concept maps in teaching History. The findings have also strong pedagogical implication since History teachers can use concept maps as an effective tool in teaching and students stand to gain more benefits through this method. In terms of the practical implications, Ministry of Education and the Teachers Training Division also should consider exposing this method to teacher trainees to equip them with pedagogical competencies to face challenges in teaching History (Al-Shaer 2014; Zwaal \& Otting, 2012).

The present study has some limitations. The effects of using the concept map method were analysed in the teaching of the Chapter on Nationalism in Malaya. More research should be conducted to investigate the effects of using this method in teaching other chapters in History. In this study only two classes of Form Two students were involved as samples; as such, it is essential to do further research to determine the effects of utilizing concept maps on a larger sample and also students of different age groups. In this study, the researcher only analysed the quantitative data. As such, it is hoped that future research will also use qualitative data to triangulate the data and investigate the effects of using the concept map method on students' achievement and interest in learning History.

\section{REFERENCES}

Al-Shaer, I.M.R. (2014). Employing concept mapping as a pre-writing strategy to help EFL learners better generate agumentative compositions. International Journal for the Scholarship of Teaching and Learning, 8(2). Retrived from http://digitalcommons.georgiasouthern.edu/ij-sotl/vol8/iss2/10/

Asan, A. (2007). Concept mapping in science class. A case study of fifth grade students. Educational Technology \& Society, 10(1), 186-195.

Ausubel, D.P. (1963). The Psychology of Meaningful Verbal Learning. New York: Grune \& Stratton Inc., Publishing.

Aziz, Z., \& Jair, N. (2009). The use of concept maps to enhance achievement in History among Form Two students. Jurnal Pendidikan Malaysia, 34(1), 3-15.

BouJaoude, S., \& Attieh, M. (2008). The effect of using concept maps as study tools on achievement in chemistry. Eurasia Journal of Mathematics, Science \& Technology Education, 4(3), 233-246.

Chiou, C.C. (2008). The effect of concept mapping on student's learning achievements and interests. Innovations in Education and Teaching International, 45(4), 375-387.

Crabtree, D. (2001). The Importance of history. Retrived from http://msc.gutenberg.edu/2001/02/the-importance-of-history/

Creswell, J.W. (2014). Educational research: Planning, conducting and evaluating quantitative and qualitative research, ( $4^{\text {th }}$ ed.), London: Pearson Educational Limited.

Gay, L.R., Mills, G.E., \& Airasian, P. (2006). Educational research: Competencies for analysis and application, ( $8^{\text {th }}$ ed.). New Jersey: Prentice Hall Publishing. 
George-Walker, L. D., \& Tyler, M. A. (2014). Collaborating concept mapping: Connecting with research team capabilities. Educational Research International. Retrived from http://www.hindawi.com/journals/edri/2014/836068/

Laporan perlaksanaan kurikulum Sejarah oleh Jemaah Nazir Sekolah Malaysia [History Curriculum implementation report by the Malaysian School Inspectorate]. (1987-1992).

Isnawati. (2000). Application of the concept of value srategies (concept mapping) to Improve the ability of Class III A students in understanding the concept of survival of organisms. Banjarmasin : Projek JSE Depdiknas Kalsel.

Jamil, H. (2003). Teknik mengajar sejarah [Techniques in teaching history]. Pahang: PTS Publication \& Distribution Sdn. Bhd.

Karakuyu, Y. (2010). The effect of concept mapping on attitude and achievement in a physics course. International Journal of the Physical Sciences, 5(6),724-737.

Kaur, R.M. (2007). Kesan penggunaan kaedah konsep map dalam pengajaran cerpen Komsas Tingkatan Satu. [The effectiveness of using concept mapping in learning short stories] (Unpublished Master's thesis). Universiti Sains Malaysia, Penang.

Kwang, F.L. (2000). Effectiveness of using concept mapping in learning - mechanism of photosynthesis among Form Four students in Chinese Girls Secondary School (Unpublished Master's thesis). Universiti Sains Malaysia, Penang.

Leibowitz, N. (2006). Active learning in the teaching of history in elementary and secondary school. Retrived from http://www.lookstein.org/articles/active_learning.pdf

Malar, M. (2010). Membanding kesan kaedah Lima Fasa Needham, kaedah STAD dan kaedah konvensional terhadap pencapaian, kemahiran sosial dan minat murid dalam pembelajaran Sejarah Tingkatan Empat [Comparing the effects of using Needham's Five Phase method, the STAD method and the conventional method on achievement, social skills and students' interest in learning Form Four History] (Unpublished Doctoral dissertation). Universiti Sains Malaysia, Penang.

Malaysian Ministry of Education. (1989). Sukatan Pelajaran Sejarah Menengah Rendah [History syllabus for lower secondary schools]. Kuala Lumpur, Malaysia: Curiculum Development Centre Publishing.

Malaysian Ministry of Education. (1998). Sukatan Pelajaran Sejarah Sekolah Menengah.[Secondary school History syllabus]. Kuala Lumpur, Malaysia: Curiculum Development Centre Publishing.

Malaysian Ministry of Education. (2002). Huraian Sukatan Pelajaran Sejarah Tingkatan Empat Kurikulum Bersepadu Sekolah Menengah [History syllabus, integrated secondary school curriculum: Form IV]. Kuala Lumpur, Malaysia: Curiculum Development Centre Publishing. 
Mason, C. L. (1992). Science Teaching and learning: using concept mapping to develop reflective practitioners. Paper presented at the Annual Meeting of the National Association for Reseach in Science Teaching, Atlanta, GA. April 1990.

Miandoah, A. D., Mostafaei, A., \& Ghaderi, D. (2012). Effects of concept mapping instruction on the academic achievement of of students in history course. Annals of Biological Research, 3(7), 3686-3690.

Mohd Din, A.M. (2005). Perceptions of form two students on learning history subject in Mukim Sungkai (Unpublished masteral thesis). Universiti Malaya, Kuala Lumpur, Malaysia.

Nair, S., \& Arumugam, R. (2006). Keberkesanan kaedah model skema bagi meningkatkan kefahaman dan minat pelajar terhadap cerpen Bahasa Melayu [The effects of utilizing schematic model to enhance interest and comprehension of Malay short stories in literature component of the Malay language among form IV students]. Malaysian Journal of Learning and Instruction, 3, 65-92.

Nair, V. J. (2009). Kesan penggunaan kosep map dalam pengajaran mata pelajaran Ekonomi Tingkatan Empat [Effects of application of concept maps in Economic subject among Form Four students] (Unpublished Master's thesis). Universiti Sains Malaysia. Penang.

Novak, J. D., \& Gowin, D. B. (1984). Learning How to Learn. New York: Cambridge University Press.

Novak, J. D. (2002). Using concept maps to facilitate classroom and distance learning. Scuola \& Catta, 2, 112-114.

Novak, J. D. (2005). Results and implications of a 12-year longitudinal study of science concept learning. Research in Science Education, 35, 23-40

Novak, J. D. (2010). Learning,Creating, and Using Knowledge: Concep Coporations. London, UK: Routledge Publishing.

Noval. J. D,. \& Canas, A. J. (2007). Theoretical origins of concept maps, how to construct them, and uses in education. Refection Education, 3, 29-42.

Pudelko, B.,Young, M., Vincent-Lammare, P., \& Charlin, B. (2012). Mapping as a learning strategy in health professions education: A critical analysis. Medical Education, $46,1215-1225$.

Sekaran, U., \& Bougie, R. (2013). Research Methods for Business (6th ed.). Italy: John Wiley \& Sons Ltd, Publishing.

Selamat, A. M. (2004). Learning for understanding: A study on effectiveness in learning History using constructivist learning theory (Unpublished Master's thesis). Tanjung Malim, Perak, Malaysia: Universiti Perguruan Sultan Idris. 
Sen@ Thomas, H. K. (2002). Kesan penggunaan peta konsep dalam pembelajaran Sains Tingkatan Satu. [The effecti of using concept maps in learning Science among Form One students] (Unpublished master's thesis). Universiti Sains Malaysia, Penang.

Steeves, K.A. (1998). Working together to strengthen history teaching in secondary schools. Retrieved from http://www.historians.org/about-aha-and-membership/ahahistory-and-archives/archives/working-together-to-strengthen-history-teaching-insecondary-school

Sundee @ Shanti, R. (2005). Kesan pendekatan model skema tehadap kefahaman sajak dalam kalangan pelajar Tingkatan Empat, [The effectiveness of using schematic model approach in comprehending poems among Form Four students] (Unpublished master's thesis). Universiti Sains Malaysia, Penang.

Thirumalar, K. (2006). Kesan Penggunaan Teknik Konsep Map Terhadap Pencapaian dan Minat Dalam Sejarah.[The effects of using concept mapping techniques on achievement and interest in history] (Unpublished Master's thesis). Universiti Sains Malaysia, Penang.

Thomas, H. (2002). Effects of using concept mapping in learning of Science (Form One). (Unpublished Master's thesis). Universiti Sains Malaysia, Penang.

Zwaal, W., \& Otting, H. (2012). The impact of concept mapping on the process of problem-based learning. Interdisciplinary Journal of Problem-based Learning, 6(1), 104-128. 


\section{Turkish Abstract}

\section{Tarih Öğretiminde Kavram Haritalarından Yararlanmanın Etkileri}

Tarih öğretmek, öğretmenler için zorlu ve zorlayıcı bir görevdir, çünkü çoğu öğrenci, Tarihi sıkıcı bir ders olarak görür. Pek çok araştırma, öğrencilerin Tarih öğrenmeyle ilgilenmediğini göstermektedir. Bu makale, orta öğretim okullarında Tarih öğretiminde konsept harita yönteminin kullanılmasının etkilerini araştırmak için yapılan yarı deneysel bir çalışmaya dayanmaktadır. Araştırmacılar, Tarih öğretiminde kavram haritalarının kullanılmasının deney grubundaki kişilere, tarih sorularına kontrol grubundan daha iyi cevap vermesinde yardımcı olup olmadığını araştırmıştır. Araştırmacılar ayrıca, bu yöntemin öğrencilerin tarih öğrenmeye olan ilgisini artırıp arttırmadığını araştırmışlardır.

Anahtar Kelimeler: tarih öğretimi, kavram haritaları, anlamlı öğrenme teorisi, Malezyalı ortaöğretim okulları

\section{French Abstract \\ Les Effets d'Utiliser les Cartes de Concept dans Histoire Enseignante}

L'enseignement de l'Histoire est une tâche dure et stimulante pour des professeurs parce que la plupart des étudiants considèrent l'Histoire un sujet ennuyeux. Beaucoup d'études indiquent que les étudiants ne sont pas intéressés par l'Histoire apprenante. Ce papier est basé sur une étude quasi-expérimentale conduite pour examiner les effets d'utiliser la méthode de carte de concept dans l'enseignement d'Histoire dans des collèges d'enseignement général. Les chercheurs ont examiné si l'utilisation de cartes de concept dans l'enseignement d'Histoire a aidé les sujets du groupe expérimental à répondre aux questions d'histoire mieux que le groupe témoin. Les chercheurs ont aussi examiné si cette méthode a aidé à améliorer l'intérêt des étudiants dans l'apprentissage d'Histoire.

Mots Clés: en enseignant histoire, cartes de concept, théorie d'apprentissage significatif, collèges d'enseignement général malais

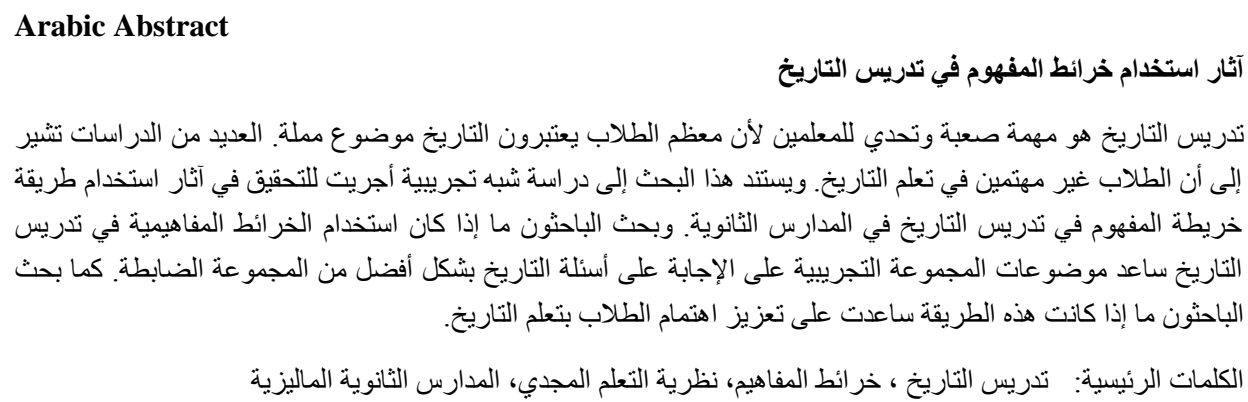




\section{German Abstract}

\section{Die Auswirkungen der Nutzung der Konzept Mappen in der Lehre Geschichte}

Lehre Geschichte ist eine schwierige und herausfordernde Aufgabe für Lehrer, weil die meisten Studenten betrachten Geschichte ein langweiliges Thema. Viele Studien zeigen, dass die Schüler nicht daran interessiert sind, Geschichte zu lernen. Dieses Papier basiert auf einer quasiexperimentellen Studie, die durchgeführt wurde, um die Auswirkungen der Nutzung der Konzeptkartenmethode in der Lehre der Geschichte in Sekundarschulen zu untersuchen. Die Forscher untersuchten, ob die Verwendung von Konzeptkarten in der Lehre der Geschichte den Probanden aus der experimentellen Gruppe half, die Geschichte besser als die Kontrollgruppe zu beantworten. Die Forscher untersuchten auch, ob diese Methode dazu beigetragen hat, das Interesse der Schüler am Lernen der Geschichte zu verbessern.

Schlüsselwörter: lehrverlauf, konzeptkarten, theorie des sinnvollen lernens, malaysische sekundarschulen

\section{Malaysian Abstract \\ Keberkesanan Penggunaan Peta Konsep dalam Pengajaran Sejarah}

Pengajaran Sejarah merupakan satu tugas yang sukar dan mencabar untuk guru-guru kerana kebanyakan pelajar menganggap Sejarah subjek membosankan. Banyak kajian menunjukkan bahawa pelajar tidak berminat untuk belajar Sejarah. Kertas kerja ini adalah berdasarkan kajian kuasi-eksperimen dijalankan untuk mengkaji kesan penggunaan kaedah peta konsep dalam pengajaran Sejarah di sekolah menengah. Para penyelidik menjalankan kajian sama ada penggunaan peta konsep dalam pengajaran Sejarah membantu mata pelajaran daripada kumpulan eksperimen untuk menjawab soalan sejarah lebih baik daripada kumpulan kawalan. Para penyelidik juga menyiasat sama ada kaedah ini membantu meningkatkan minat pelajar dalam pembelajaran Sejarah.

Kata Kunci: pengajaran sejarah, peta konsep, teori pembelajaran bermakna, sekolah menengah di Malaysia

\section{Russian Abstract \\ Эффекты Использования Концептуальных Карт в Истории Преподавания}

Преподавание Истории - сложная и трудная задача для учителей, потому что большинство студентов считают историю скучным предметом. Многие исследования показывают, что студенты не заинтересованы в изучении истории. Настоящая статья основана на квазиэкспериментальном исследовании, проведенном для изучения эффектов использования метода карт понятий в преподавании истории в средних классах. Исследователи показали: помогло ли использование концептуальных карт в преподавании истории предметам экспериментальной группы, лучше отвечать на вопросы истории, чем контрольная группа. Исследователи также выяснили, помог ли этот метод повысить интерес учащихся к изучению истории.

Ключевые Слова: истории преподавания, концептуаль карты, теория осмысленного обучения, малазийские средние школы 